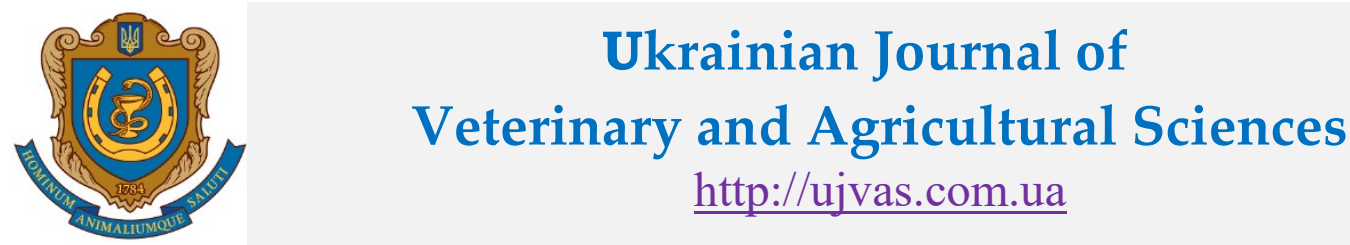

Stepan Gzhytskyi National University of Veterinary Medicine and Biotechnologies Lviv

\begin{tabular}{l|l|l} 
original article & UDC 619:612.12:615.9 & doi: $\mathbf{1 0 . 3 2 7 1 8 / u j v a s 2 - 3 . 0 4}$
\end{tabular}

Volume 2

Number 3

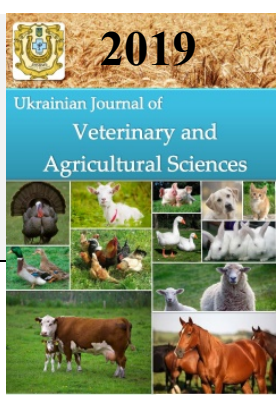

\title{
The level of lipid peroxidation products in the rats blood under prolonged cadmium and lead loading
}

\author{
S. O. Slobodian, B. V. Gutyj, K. Y. Leskiv \\ Stepan Gzhytskyi National University of Veterinary Medicine and Biotechnologies, Pekarska, Str., 50, Lviv, 79010, Ukraine
}

\begin{abstract}
Article info
Received 01.11.2019

Received in revised form 04.12 .2019

Accepted 05.12.2019

Correspondence author

Solomiya Slobodyan

Tel.: +38-067-316-74-30

E-mail: solomiaslobodian@ukr.net

2019 Slobodyan S. O. et al. This is an open-access article distributed under the terms of the Creative Commons Attribution License, which permits unrestricted use, distribution, and reproduction in any medium, provided the original author and source are credited.

\section{(cc) $\mathrm{BY}$}

Contents

1. Introduction

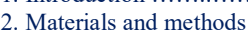

. Materials and methods ...... 16

3. Results and discussion ...... 16

4. Conclusions ................ 17

References .................... 17

Abstract

Lipid peroxidation is a form of tissues respiration. This process is characteristic of normal tissues and occurs, as a rule, after the construction of lipid membrane structures, their updates and during the biosynthesis of many hormones. However, free radical oxidation can be activated in an unfavorable environmental situation, since in our case it happened under the action of Cadmium and Lead. The purpose of the work was to investigate the Cadmium and Lead effects on the lipid peroxidation processes intensity in rats. The experiments were carried out on $200-$ $220 \mathrm{~g}$ male "Wistar" rats, from which 4 groups of animals were formed: 1) control group - animals were administered drinking water through a metal probe in bulk, which is equivalent to the volume of aqueous salt solution $\mathrm{Cd}^{2+} \mathrm{i} \mathrm{Pb}^{2+} ; 2$ ) experimental group 1 - animals were administered $0.029 \%$ an aqueous solution of cadmium chloride in a dose $4.0 \mathrm{mg} / \mathrm{kg}$; 3) experimental group 2 - animals were administered $16.6 \%$ aqueous lead acetate solution at a dose $200 \mathrm{mg} / \mathrm{kg}$; 4) experimental group 3 - animals were administered $16.6 \%$ aqueous lead acetate solution at a dose $100 \mathrm{mg} / \mathrm{kg}$ and $0.029 \%$ an aqueous solution of cadmium chloride in a dose $2.0 \mathrm{mg} / \mathrm{kg}$. Throughout the experiment, rats were kept in a balanced diet containing all the necessary components, the animals were given drinking water without restrictions from 0.2 liter glass bowls. Based on our research, we detected activation of lipid peroxidation (LPO) products in the blood of rats under lead-cadmium loading, as indicated by the growth of intermediate and final products in comparison with the group of intact animals. Probable level increase of LPO products was observed from the first day of the experiment. For the 7th day of the experiment, the level of diene conjugates in the blood of the third experimental group increased by $88.9 \%$, and the level of Thiobarbituric acid reactive substances (TBARS) increased by $31.8 \%$. At 14 and 21 days of the experiment, the level of of LPO products in the rats blood under the lead-cadmium load was the highest. These changes in the LPO products level indicate an increase in the intensity of radical formation processes. Peroxide oxidation forms, at almost all stages of its course, a number of products that result from the interaction of free radicals with each other and with biological macromolecules.
\end{abstract}

Key words: toxicology, cadmium, lead, rats, diene conjugates, TBARS-active products

\section{Citation:}

Slobodian, S. O., Gutyj, B. V., \& Leskiv, K. Y. (2019). The level of lipid peroxidation products in the rats blood under prolonged cadmium and lead loading. Ukrainian Journal of Veterinary and Agricultural Sciences, 2(3), 15-18.

\section{Introduction}

The problem of environmental pollution by Cadmium and Lead, which is one of the consequences of the intensification of industrial and agrarian production, has become especially relevant now (Ali et al., 1986; Myslyva, 2013; Hutyi, 2015; Gutyj et al., 2018; 2019). The growth of these metals content in Ukrainian soils and other countries over the last decades has been accompanied by the accumulation of $\mathrm{Cd}^{2+}$ and $\mathrm{Pb}^{2+}$ in agricultural products and feed, thus increases the threat to human and animal health (Myslyva, 2013; Lavryshyn \& Gutyj, 2019; Kuras \& Ersteniuk, 2019).

The results of many important experimental studies indicate that Cadmium and Lead have a toxic effect on a number of organs and systems in the body of mammals (Marushko et al., 2010; Petrynych et al., 2017; Ostapyuk \& Gutyj, 2018; 2019). Lead and Cadmium are easily associated with thiol groups of apoenzymes when released into the body of animals, and thus switch the activity of the antioxidant protection, microsomal and other enzymatic systems, affect the exchange of macro and microelements, have a carcinogenic effect (Al-Azemi et al., 2010; Stepanchuk, 2014; Lavryshyn et al., 2018; 2019).

Although there are many works in the literature on the mechanisms of Lead and Cadmium negative effects on the organism of laboratory and farm animals, however the question of functional changes and the state of the antioxidant system in liver cells under the combined effects of these metals remains relevant.

The purpose of the work was to investigate the Cadmium and Lead impact on the intensity of lipid peroxidation processes in rats. 


\section{Materials and methods}

The experiments were carried out in 200-220 g male "Wistar" rats, from which 4 groups of animals were formed:

1 - control group - animals were administered drinking water through a metal probe in bulk, which is equivalent to

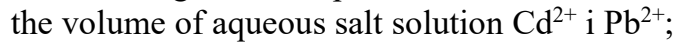

2) - experimental group 1 - animals were administered $0,029 \%$ an aqueous solution of cadmium chloride in a dose $4.0 \mathrm{mg} / \mathrm{kg}$;

3) - experimental group 2 - animals were administered $16.6 \%$ aqueous lead acetate solution at a dose $200 \mathrm{mg} / \mathrm{kg}$;

4) - experimental group 3 - animals were administered $16.6 \%$ aqueous lead acetate solution at a dose $100 \mathrm{mg} / \mathrm{kg}$ and $0.029 \%$ an aqueous solution of cadmium chloride in a dose $2.0 \mathrm{mg} / \mathrm{kg}$.

Throughout the experiment, rats were kept in a balanced diet containing all the necessary components, and were given drinking water without restrictions from 0.2 liter glass bowls.

All animal manipulations were carried out in accordance with the European Convention on the Protection of Vertebrate Animals Used for Experimental and Scientific Purposes (Strasbourg, 1986).

Blood for biochemical studies was collected under ether anesthesia from the jugular vein on 1, 7, 14, 21 and 28 days of the experiment. The level of diene conjugates and TBARS active products was studied by the method (Vlizlo, 2012).

The Statistica 6.0 software package was performed for analysis of the research. The reliability of difference between the groups was assessed by Student's t-test. The results were considered plausible at $\mathrm{P} \leq 0.05$.

\section{Results and discussion}

Lipid peroxidation (LPO) is one of the most important oxidation processes in the animal body. Actually LPO is considered to be one of the major causes of cell damage and death due to the action of reactive oxygen species (ROS) and free radicals. It is known that any sufficiently powerful environmental impact on the animal body can initiate processes of LPO. It is established that the LPO processes in the rats body under cadmium loading enhanced, this is indicated by an increase in the level of intermediates and end LOPs, specifically diene conjugates and TBARS active products (Table 1).

Credible increase of diene conjugates was noted on the first day of the experiment in the blood of the first experimental group, in which this investigated indicator raised up by $20.6 \%$ compared to the control group. Subsequently, the level of DC continued to grow and accordingly grew up by $85.5 \%$ on the 7 th day, 2.1 times on the 14 th day in the rats of this group. And for the 21 st day of the experiment, the level of the investigated indicator increased to $1.015 \pm$ $0.023 \mathrm{c} / \mathrm{u} . / \mathrm{ml}$.

Similar changes are observed in the study of the TBARS-active products level, which also increased for 1 day of the experiment. At the 7 th day of the experiment, the level of the final product of the LPO credible raised by $30.4 \%$, and by the 14 th day - by $56.8 \%$ relative to the control. The level of TBARS-active products increased to $11.12 \pm 0.22 \mu \mathrm{mol} / 1$ at the $21 \mathrm{st}$ day of the experiment, whereas in the control this indicator was equal to $6.41 \pm$ $0.10 \mu \mathrm{mol} / 1$.

The study of the effect of lead on the rats of the second experimental group showed an increase in the level of diene conjugates and TBARS-active products in comparison with the control group for 1 day of the experiment by 19.0 and $11.7 \%$ (Table 2 ). At the 7 th day of the research, the intermediate and final products of LPO were credible raised by 76.1 and $23.6 \%$, respectively. The level of diene conjugates and TBARS-active products in the blood rats of the second experimental group increased to $0.986 \pm 0.020 \mathrm{c} / \mathrm{u} / \mathrm{ml}$ and $10.41 \pm 0.20 \mu \mathrm{mol} / 1$ for 21 days of experience. For the 28 th day of the experiment, the level of LPO products remained high.

Table 1

The level of LPO products in the rats serum under cadmium loading $(M \pm m, n=6)$

\begin{tabular}{|c|c|c|c|c|c|c|}
\hline \multirow{3}{*}{ Indicators } & \multicolumn{6}{|c|}{ Groups } \\
\hline & \multirow[t]{2}{*}{ Control } & \multicolumn{5}{|c|}{$\begin{array}{l}1 \text { experimental; } \\
\text { experiment day }\end{array}$} \\
\hline & & 1 & 7 & 14 & 21 & 28 \\
\hline $\mathrm{DC}, \mathrm{c} . \mathrm{u} / \mathrm{ml}$ & $0.461 \pm 0.011$ & $\begin{array}{c}0.556 \pm 0.013 \\
* * *\end{array}$ & $\begin{array}{c}0.855 \pm 0.020 \\
* * *\end{array}$ & $\begin{array}{c}0.970 \pm 0.019 \\
* * *\end{array}$ & $\begin{array}{c}1.015 \pm 0.023 \\
* * *\end{array}$ & $\begin{array}{c}0.779 \pm 0.016 \\
* * *\end{array}$ \\
\hline $\begin{array}{l}\text { TBARS-active } \\
\text { products, } \mu \mathrm{mol} / 1\end{array}$ & $6.41 \pm 0.10$ & $\begin{array}{c}7.30 \pm 0.12 \\
* * *\end{array}$ & $\begin{array}{c}8.36 \pm 0.17 \\
* * *\end{array}$ & $\begin{array}{c}10.05 \pm 0.24 \\
* * *\end{array}$ & $\begin{array}{c}11.12 \pm 0.22 \\
* * *\end{array}$ & $\begin{array}{c}8.68 \pm 0.19 \\
* * *\end{array}$ \\
\hline
\end{tabular}

Table 2

The level of LPO products in the rats serum under lead loading $(M \pm m, n=6)$

\begin{tabular}{|c|c|c|c|c|c|c|}
\hline \multirow{3}{*}{ Indicators } & \multicolumn{6}{|c|}{ Groups } \\
\hline & \multirow[t]{2}{*}{ Control } & \multicolumn{5}{|c|}{$\begin{array}{l}2 \text { experimental; } \\
\text { experiment day }\end{array}$} \\
\hline & & 1 & 7 & 14 & 21 & 28 \\
\hline DC, c.u./ml & $0.461 \pm 0.011$ & $\begin{array}{c}0.549 \pm 0.011 \\
* * *\end{array}$ & $\begin{array}{c}0.812 \pm 0.019 \\
* * *\end{array}$ & $\begin{array}{c}0.943 \pm 0.017 \\
* * *\end{array}$ & $\begin{array}{c}0.986 \pm 0.020 \\
* * *\end{array}$ & $\begin{array}{c}0.732 \pm 0.016 \\
* * *\end{array}$ \\
\hline $\begin{array}{l}\text { TBARS-active } \\
\text { products, } \mu \mathrm{mol} / 1\end{array}$ & $6.41 \pm 0.10$ & $\begin{array}{c}7.16 \pm 0.14 \\
* *\end{array}$ & $\begin{array}{c}7.92 \pm 0.15 \\
* * *\end{array}$ & $\begin{array}{c}9.75 \pm 0.24 \\
* * *\end{array}$ & $\begin{array}{c}10.41 \pm 0.20 \\
* * *\end{array}$ & $\begin{array}{c}8.13 \pm 0.14 \\
* * *\end{array}$ \\
\hline
\end{tabular}


The highest levels of diene conjugates and TBARSactive products, were established with the combined use of Cadmium and Lead compared to the first and second study groups (Table 3). Credible growth in the level of LPO products has been observed since the first day of the experiment. The level of diene conjugates in the blood of the third experimental group grew up by $88.9 \%$, and the level of TBARS- active products - by $31.8 \%$ for 7 th day of the research. At the 14th and 21st day of the experiment, the level of LPO products in the blood of rats under lead-cadmium load was the highest and fluctuated, respectively, within the diene conjugates of $0.986 \pm 0.011$ and $1.026 \pm 0.021$ c.u. $/ \mathrm{ml}$ and TBARS-active products $-10.23 \pm 0.24$ and $11.29 \pm$ $0.20 \mu \mathrm{mol} / 1$.

Table 3

The level of LPO products in the rats serum under lead-cadmium lead loading $(M \pm m, n=6)$

\begin{tabular}{|c|c|c|c|c|c|c|}
\hline \multirow{3}{*}{ Indicators } & \multicolumn{6}{|c|}{ Groups } \\
\hline & \multirow[t]{2}{*}{ Control } & \multicolumn{5}{|c|}{$\begin{array}{l}3 \text { experimental; } \\
\text { experiment day }\end{array}$} \\
\hline & & 1 & 7 & 14 & 21 & 28 \\
\hline DC, c.u./ml & $0.461 \pm 0.011$ & $\begin{array}{c}0.549 \pm 0,019 \\
* * *\end{array}$ & $\begin{array}{c}0.871 \pm 0,022 \\
* * *\end{array}$ & $\begin{array}{c}0.986 \pm 0.011 \\
* * *\end{array}$ & $\begin{array}{c}1.026 \pm 0.021 \\
* * *\end{array}$ & $\begin{array}{c}0.812 \pm 0.015 \\
* * *\end{array}$ \\
\hline $\begin{array}{l}\text { TBARS-active } \\
\text { products, } \mu \mathrm{mol} / 1\end{array}$ & $6.41 \pm 0.10$ & $\begin{array}{c}7.36 \pm 0.10 \\
* * *\end{array}$ & $\begin{array}{c}8.45 \pm 0.18 \\
* * *\end{array}$ & $\begin{array}{c}10.23 \pm 0.24 \\
* * *\end{array}$ & $\begin{array}{c}11.29 \pm 0.20 \\
* * *\end{array}$ & $\begin{array}{c}8.87 \pm 0.16 \\
* * *\end{array}$ \\
\hline
\end{tabular}

At the 28th day of the research, the level of LPO intermediate products in the blood of rats of the third experimental group increased by $76.1 \%$, and the level of TBKactive products - by $38.4 \%$ relative to the control group.

Accordingly, introduction of Cadmium and Lead salts into the body leads to the accumulation of both intermediate and final LPO products. These changes in the level of LPO products indicate an increase in the intensity of radical formation processes. Peroxide oxidation forms, at almost all stages of its course, a number of products which result from the interaction of free radicals with each other and with biological macromolecules.

Lipid peroxidation is a form of tissue respiration. This process is characteristic of normal tissues and occurs, as a rule, after the construction of lipid membrane structures, their updates and during the biosynthesis of many hormones (Martyshuk et al., 2016). However, free radical oxidation can be activated in an unfavorable environmental situation, since in our case it happened under the action of Cadmium and Lead.

It is known that free radical lipid peroxidation is an important stage of the body's damage by heavy metals, and the newly formed products of this process (hydroperoxides and peroxides of organic substrates) cause a pronounced damaging effect on cell membranes and activate lipid peroxidation in them (Lavryshyn et al., 2016). This leads to disruption of the structure and integrity of the membranes, and also causes changes in the system of acid-base status of the blood with the subsequent activation of lipid peroxidation, which is accompanied by changes in the functioning of iontransport systems.

Excessive activation of LPO processes leads to disruption of the structure of membranes, lipid metabolism, has a toxic effect on tissues, promotes oxidation of sulfhydryl groups of proteins, enhances lysis, leads to the development of structural changes after diseases of the cardiovascular, respiratory and digestive systems (Zhukova et al., 2016; Martyshuk et al., 2016).

Based on our research, we detected the activation of LPO in the blood of rats under lead-cadmium loading, which indicates an increase in intermediate and final products in comparison with the group of intact animals (Lavryshyn et al., 2016). Possibly, such changes may be due to the fact that in the mechanisms of toxic action of cadmi- um and lead an important role is played by stimulating the formation of free radicals and active forms of oxygen, resulting in a balance between the content of oxidants and antioxidants (Hutyi, 2015).

The increase in LPO processes intensity found in our experiments is apparently related to the development of hypoxia, which is dominated by anaerobic processes of metabolism in tissues.

\section{Conclusions}

A series of experiments allowed to establish a significant disturbance of the oxidation-antioxidant equilibrium in animals under the conditions of lead-cadmium loading, which is characterized, first of all, by the activation of the processes of free radical oxidation of lipids with excessive accumulation of both intermediate and final floor products contents. Therefore, it was found that the modeling of lead-cadmium toxicosis in rats of the third experimental group leads to a significant increase in the content of diene conjugates and TBARS-active products in the blood of animals in 2.23 and 1.59 times compared with intact animals.

\section{References}

Al-Azemi, M., Omu, F. E., Kehinde, E. O., Anim, J. T., Oriowo, M. A., \& Omu, A. E. (2010). Lithium protects against toxic effects of cadmium in the rat testes. J. Assist. Reprod. Genet, 27(8), 469-476. doi: 10.1007/s10815-010-9426-3.

Ali, M. M., Murthy, R. C., \& Chandra, S. V. (1986). Developmental and longterm neurobehavioral toxicity of low-level in utero $\mathrm{Cd}$ exposure in rats. Neurobehavioral Toxicology and Teratology, 8(5), 463-468. https://www.ncbi.nlm.nih.gov/pubmed/ 3785508

Gutyi, B., Ostapiuk, A., Kachmar, N., Stadnytska, O., Sobolev, O., Binkevych, V., Petryshak, R., Petryshak, O., Kulyaba, O., Naumyuk, A., Nedashkivsky, V., Nedashkivska, N., Magrelo, N., Golodyuk, I., Nazaruk, N., \& Binkevych, O. (2019). The effect of cadmium loading on protein synthesis function and functional state of laying hens' liver. Ukrainian Journal of Ecology, 9(3), 222-226. https://www.ujecology.com/ abstract/the-effect-of-cadmium-loading-on-protein-synthesisfunction-and-functional-state-of-laying-hens-liver-44516.html.

Gutyj, B. V., Gufriy, D. F., Binkevych, V. Y., Vasiv, R. O., Demus, N. V., Leskiv, K. Y., Binkevych, O. M., \& Pavliv, O. V. (2018). Influence of cadmium loading on glutathione system 
of antioxidant protection of the bullocks'bodies. Scientific Messenger of Lviv National University of Veterinary Medicine and Biotechnologies, 20(92), 34-40. doi: 10.32718/nvlvet9207.

Hutyi, B. V. (2015). Aktyvnist systemy antyoksydantnoho zakhystu orhanizmu bychkiv za hostroho kadmiievoho toksykozu. Naukovyi visnyk Lvivskoho natsionalnoho universytetu veterynarnoi medytsyny ta biotekhnolohii im. Gzhytskoho, 17, 1(1), 31-36. Rezhym dostupu: http://nbuv.gov.ua/UJRN/nvlnu_2015_17 _1(1)_8 (in Ukrainian).

Kuras, L. D., \& Ersteniuk, H. M. (2019). Pokaznyky enerhetychnoho obminu v sertsevii tkanyni eksperymentalnykh tvaryn za umov vplyvu kadmii khlorydu. Medychna ta klinichna khimiia, 21(1), 25-31. Rezhym dostupu: http://nbuv.gov.ua/UJRN/Medkh 2019 21_1_6 (in Ukrainian).

Lavryshyn, Y. Y., \& Gutyj, B. V. (2019). Protein synthesize function of bulls liver at experimental chronic cadmium toxicity. Scientific Messenger of Lviv National University of Veterinary Medicine and Biotechnologies. Series: Veterinary sciences, 21(94), 92-96. doi: 10.32718/nvlvet9417.

Lavryshyn, Y. Y., Gutyj, B. V., Palyadichuk, O. R., \& Vishchur, V. Y. (2018). Morphological blood indices of bulls in experimental chronic cadmium toxicosis. Scientific Messenger of Lviv National University of Veterinary Medicine and Biotechnologies, 20(88), 108-114. doi: 10.32718/nvlvet8820.

Lavryshyn, Y. Y., Gutyj, B. V., Paziuk, I. S., Levkivska, N. D., Romanovych, M. S., Drach, M. P., \& Lisnyak, O. I. (2019). The effect of cadmium loading on the activity of the enzyme link of the glutathione system of bull organism. Scientific Messenger of Lviv National University of Veterinary Medicine and Biotechnologies. Series: Veterinary sciences, 21(95), 107-111. doi: 10.32718/nvlvet9520.

Lavryshyn, Y. Y., Varkholyak, I. S., Martyschuk, T. V., Guta, Z. A., Ivankiv, L. B., Paladischuk, O. R., Murska, S. D., Gutyj, B. V., \& Gufriy, D. F. (2016). The biological significance of the antioxidant defense system of animals body. Scientific Messenger LNUVMBT named after S. Z. Gzhytskyj, 18, 2(66), 100111. doi: 10.15421/nvlvet6622.

Marushko, Yu.V., Tarynska, O.L., Olefir, T.I., \& Fus, S.V. (2010). Kadmii: nakopychennia ta vplyv na orhanizm dytyny. Medychna nauka Ukrainy, 3, 62-67. Rezhym dostupu: http://nbuv.gov.ua/UJRN/nvnmu 2010312 (in Ukrainian).

Martyshuk, T. V., Gutyj, B. V., \& Vishchur, O. I. (2016). Level of lipid peroxidation products in the blood of rats under the influ- ence of oxidative stress and under the action of liposomal preparation of "Butaselmevit". Biological Bulletin of Bogdan Chmelnitskiy Melitopol State Pedagogical University, 6(2), 22 27. doi: $10.15421 / 201631$.

Myslyva, T. M. (2013). Svynets i kadmii u hruntakh ahrolandshaftiv Zhytomyrskoho Polissia. Visnyk Sumskoho natsionalnoho ahrarnoho universytetu. Seriia: Ahronomiia $i$ biolohiia, 3, 43-50. Rezhym dostupu: http://nbuv.gov.ua/UJRN/Vsna_agro_2013 3_13 (in Ukrainian).

Myslyva, T. M. (2013). Svynets i kadmii u hruntakh pryrodnykh i ahrolandshaftiv Zhytomyrskoho Polissia. Visnyk Zhytomyrskoho natsionalnoho ahroekolohichnoho universytetu, 1(1), 36-49. Rezhym dostupu: http://nbuv.gov.ua/UJRN/Vzhnau 2013_1(1)_8 (in Ukrainian).

Ostapyuk, A. Y., \& Gutyj, B. V. (2018). Influence of cadmium loading on morphological parameters of blood of the Laying Hens. Scientific Messenger of Lviv National University of Veterinary Medicine and Biotechnologies, 20(88), 48-52. doi: $10.32718 /$ nvlvet 8808 .

Ostapyuk, A. Y., \& Gutyj, B. V. (2019). Influence of cadmium sulfate at different doses on the functional state of the liver of laying chicken. Scientific Messenger of Lviv National University of Veterinary Medicine and Biotechnologies. Series: Veterinary sciences, 21(94), 103-108. doi: 10.32718/nvlvet9419.

Petrynych, V. V., Vlasyk, L. I., \& Petrynych, O. A. (2017). Svynets: toksykolohichni, hihiienichni ta biolohichni aspekty. Klinichna ta eksperymentalna patolohiia, 16(2), 97-102. Rezhym dostupu: http://nbuv.gov.ua/UJRN/kep_2017 16222 (in Ukrainian).

Stepanchuk, V. V. (2014). Ontohenetychni osoblyvosti tsyrkadiannykh khronorytmiv vilnoradykalnoho homeostazu za umov svyntsevoho otruiennia. Klinichna ta eksperymentalna patolohiia, 13(2), 131-133. Rezhym dostupu: http://nbuv.gov.ua/UJRN/kep 2014 13233 (in Ukrainian).

Vlizlo, V. V., Fedoruk, R. S., \& Ratych, I. B. (2012). Laboratorni metody doslidzhen $\mathrm{u}$ biolohii, tvarynnytstvi ta veterynarnii medytsyni. Dovidnyk. za red. Vlizla, V.V. Lviv. SPOLOM (in Ukrainian)

Zhukova, I. O., Svitlychna-Kulak, Yu. S., \& Longus, N. I. (2016). Correction of stateof antioxidant protection in dogs when poisoned byneoverm. Scientific Messenger LNUVMBT named after S. Z. Gzhytskyj, 18, 3(70), 95-99. doi: 10.15421/nvlvet7022. 